A N N A L E S

UNIVERSITATIS MARIAE CURIE-SKŁODOW K A

LUBLIN - POLONIA

VOL. LXXIII

SECTIO B

2018

\author{
MARTA SIDORKIEWICZ \\ ORCID ID 0000-0001-7559-7794 \\ Wydział Zarządzania i Ekonomiki Usług \\ Uniwersytet Szczeciński \\ marta.sidorkiewicz@wzieu.pl
}

\title{
Identyfikacja atrybutów hoteli inteligentnych w Polsce w kontekście potrzeb noclegowych pokolenia Y
}

\author{
Attributes identification of smart hotel in Poland in the context \\ of the accommodation needs for generation $\mathrm{Y}$
}

\begin{abstract}
The needs of guests belonging to the $\mathrm{Y}$ generation are the basis for the functioning of smart hotels. Their needs determine the need to introduce changes in the activities of the hospitality in connection with the creation of new types of hotel objects. The aim of the article is to identify the attributes of accommodation facilities referred to as smart hotels on the domestic hotel market in the context of accommodation needs of the $\mathrm{Y}$ generation. The content of the study is the result of using, above all, the research method of desk research in the form of literature analysis of the subject, online resources and industry reports. In addition, logical operations methods (primarily deductions and inductions) were used.
\end{abstract}

Keywords: hospitality, smart hotel, generation Y, accommodation needs

Abstrakt: Potrzeby współczesnych gości należących do pokolenia Y stanowią przesłanki dla funkcjonowania hoteli inteligentnych. To właśnie one determinują konieczność wprowadzania zmian w podejmowanych przez branżę hotelarską działaniach w ramach kreowania nowych rodzajów obiektów hotelarskich. Celem artykułu jest zidentyfikowanie atrybutów obiektów noclegowych określanych mianem hoteli inteligentnych (hoteli smart) na krajowym rynku hotelarskim w kontekście potrzeb noclegowych pokolenia Y. Ponadto podjęto próbę zdefiniowania tego rodzaju obiektów. Treść opracowania jest wynikiem wykorzystania przede wszystkim metody badawczej desk research w postaci analizy literatury przedmiotu, zasobów internetowych oraz doniesień branżowych. Ponadto zostały wykorzystane metody operacji logicznych (przede wszystkim dedukcji i indukcji).

Słowa kluczowe: hotelarstwo, hotel inteligentny (smart), pokolenie Y, potrzeby noclegowe 


\section{WPROWADZENIE}

Cechą charakterystyczną egzystencji współczesnego człowieka, a zwłaszcza tego należącego do pokolenia $\mathrm{Y}$, jest fakt, iż coraz większa liczba procesów życiowych przebiega w wymiarze wirtualnym, zastępując w części lub całości procesy realne. Wynika to $\mathrm{w}$ dużej mierze $\mathrm{z}$ postępu technologicznego związanego z dużym wskaźnikiem korzystania z telefonów komórkowych i z zainstalowanych na nich aplikacji. Taki stan rzeczy może powodować zmiany potrzeb w zakresie nabywania i konsumowania określonej oferty, w tym hotelarskiej.

Nowy styl życia ludzi wpływający na nowe ich potrzeby noclegowe to w konsekwencji zmiany na rynku hotelarskim. Odpowiedzią na nowe zapotrzebowanie w tym zakresie może być oferta obiektów noclegowych określanych mianem hoteli inteligentnych lub hoteli smart.

Celem artykułu jest zidentyfikowanie atrybutów obiektów noclegowych określanych mianem hoteli inteligentnych (hoteli smart) na krajowym rynku hotelarskim w kontekście potrzeb noclegowych pokolenia Y. Ponadto podjęto próbę zdefiniowania tego rodzaju obiektów.

Na uwage zasługuje fakt, iż na polskim rynku wydawniczym brakuje publikacji naukowych związanych z omawianym tematem, co stanowi jedno z głównych przesłanek podjęcia niniejszego tematu.

Treść opracowania ma charakter przeglądowy i jest wynikiem wykorzystania przede wszystkim metody badawczej desk research w postaci analizy polskiej i zagranicznej literatury przedmiotu z zakresu hotelarstwa, marketingu, zarządzania, innowacji i demografii, zasobów internetowych ${ }^{1}$ oraz krajowych czasopism branżowych ${ }^{2}$. Ponadto zostały wykorzystane metody operacji logicznych (przede wszystkim dedukcji i indukcji).

\section{POTRZEBY POKOLENIA Y W KREOWANIU NOWEGO TYPU OBIEKTÓW HOTELARSKICH. PRZESŁANKI DLA FUNKCJONOWANIA HOTELI INTELIGENTNYCH}

Gość hotelowy w XXI w. nie jest już tym samym klientem, z którym obiekty hotelarskie miały do czynienia $w$ wieku ubiegłym. Spowodował to m.in. rozwój nowoczesnych technologii i związany z tym dostęp do informacji (Gołąb-Andrzejak 2016). Przedsiębiorstwa turystyczne, w tym hotelarskie, zawsze były liderami wprowadzania technologii w swoich działaniach z zakresu dystrybucji,

\footnotetext{
1 Przede wszystkim stron internetowych zidentyfikowanych hoteli inteligentnych.

2 Analizowano zwłaszcza czasopismo dla branży hotelarskiej „Hotelarz”, zakres czasowy: 2006-2018.
} 
promocji oraz automatyzacji wewnętrznych procesów firmy. Wiodąca pozycja przedsiębiorstw turystycznych w implementacji rozwiązań informatycznych wynika z faktu, iż w dużej części produkt turystyczny ma charakter niematerialny, który opiera się na zaufaniu, konieczności dostarczenia klientowi znacznej ilości informacji oraz licznych powiązaniach pomiędzy różnymi przedsiębiorstwami turystycznymi funkcjonującymi w różnych regionach świata (Pawlicz 2012). Te i inne elementy złożyły się na nieodzowność wprowadzania zmian w podejmowanych przez branżę hotelarską działaniach w ramach kreowania nowych rodzajów obiektów hotelarskich.

Biorąc pod uwagę statystyki dotyczące demografii, w 2020 roku pokolenie Y (zwane również pokoleniem Millenialsów) stanowić będzie ponad 50\% wszystkich gości hotelowych (Hotel Marketing \& Technology... 2017). W 2016 r. grupa ta liczyła w Polsce już około 9 mln osób. Ze względu na tak dużą liczebność oraz fakt, że to właśnie te osoby nabywają i wydają najwięcej środków finansowych na otaczające ich dobra, stanowią one dla oferentów rynkowych jedną z najważniejszych grup docelowych. To dla nich tworzone są dedykowane strategie marketingowe i to właśnie oni dyktują zmiany w ofercie przedsiębiorstw (Stańczak 2017).

Pokolenie Y to grupa społeczna, wokół której współcześnie prowadzi się liczne rozważania teoretyczno-empiryczne. Analizując literaturę przedmiotu, stosunkowo wiele publikacji dotyczy tej generacji w aspekcie rynku pracy (charakterystyka potrzeb pracowników generacji Y a problemy ze sposobem zarządzania tą grupa) (Aruna i in. 2015; Brown i in. 2015; Kultalahti i in. 2015).

W literaturze przedmiotu, zarówno krajowej, jak i zagranicznej, toczy się dyskusja na temat horyzontu czasowego, który opisuje ten segment rynku. Ze względu na rozbieżność zdań w tym obszarze na potrzeby niniejszego artykułu przyjęto założenie, że to pokolenie stanowią osoby urodzone w latach osiemdziesiątych i dziewięćdziesiątych XX wieku (Gołąb-Andrzejak 2016). Kontynuując zagadnienie zakresu czasowego, z pewnością należy podkreślić fakt, iż ta grupa klientów słabo pamięta okres PRL-u, więc nie „odcisnął” on na nich takiego piętna jak na wcześniejszych generacjach. Od rodziców dostali oni wsparcie zarówno emocjonalne, jak i edukacyjne, dzięki któremu mają wysokie poczucie własnej wartości i silne przekonanie o własnych kompetencjach (Kot 2016).

$\mathrm{O}$ ile nie ma zgodności autorów zajmujących się tematem pokolenia $\mathrm{Y}$ co do zakresu czasowego opisującego tę generację, o tyle według badań przeprowadzonych w University of New Hampshire pokolenie Y stanowią osoby (Gołąb-Andrzejak 2016):

- dobrze wykształcone i chcące dalej się rozwijać,

- aktywne, 
- wykorzystujące w każdej dziedzinie życia nowoczesne technologie,

- będące ,globalnymi obywatelami świata” żyjącymi w „globalnej wiosce" - dzięki dostępowi do Internetu mają bowiem znajomości na całym świecie,

- charakteryzujące się dużą pewnością siebie,

- dłużej mieszkające z rodzicami, odsuwając w ten sposób w czasie przejście w dorosłość,

- przypisujące duże znaczenie jakości życia i doświadczeniu życiowemu, a nie posiadaniu,

- tolerancyjne i otwarte,

- przekonane o własnej wyjątkowości, z wysokim mniemaniem na temat swoich umiejętności, co rodzi silną awersję wobec krytyki,

- umiejące skoncentrować uwagę przede wszystkim w krótkim czasie.

Duży wpływ na kształtowanie pokolenia Y miały technologie informacyjno-komunikacyjne (Bolton i in. 2013), których rozwój przyczynił się do powstania większej niż kiedykolwiek w historii przepaści międzypokoleniowej (Kachniewska i in. 2014). Pokolenie Y jest pierwszym, które praktycznie całe swoje życie spędziło w tzw. środowisku cyfrowym, stanowiąc wyzwanie dla osób zajmujących się marketingiem.

Ten segment rynku jest mocno związany z nową technologią i oczekuje wysokiej jakości udogodnień, także w podróży. Aby spełnić ich wymagania, obiekty hotelarskie powinny więc stosować inteligentne rozwiązania, wykorzystując w głównej mierze technologie mobilne (Hotel Marketing \& Technology... 2017), które w coraz większym stopniu stają się nieodłącznym elementem życia współczesnego człowieka. Jak wynika $\mathrm{z}$ badań przeprowadzonych przez niemiecką agencję Fraunhofer IAO we współpracy z portalem rezerwacji hotelowych HRS, 34\% gości w Polsce wolałoby obsługiwać światło, klimatyzację i telewizję poprzez smarfona lub tablet, czyli przez jeden ekran, zamiast na przykład używać różnych pilotów lub włączników („Hotelarz” 2014).

Nabywcy produktów generacji Y przyzwyczaili się, że coraz więcej aktywności można realizować bez opuszczania gospodarstwa domowego i tego samego oczekują po przyjeździe do obiektu hotelarskiego. Rozwój technologii sprawił więc, że potrzeby noclegowe gości uległy diametralnej zmianie. Współcześni goście nie chcą stać w kolejkach, wychodzić z jednostki mieszkalnej, a coraz częściej nie chcą nawet wchodzić w interakcję z personelem obsługowym. Nowoczesny klient oczekuje, że sam wybierze najbardziej dogodny sposób realizacji usługi, w zależności od jego aktualnych potrzeb. Czołowe sieci hotelowe na świecie już dawno zauważyły ten trend i zaczęły wprowadzać innowacje technologiczne w świadczonej ofercie, co w efekcie stanowiło bazę do powstania 
tzw. hoteli inteligentnych (Hotel Marketing \& Technology... 2017), zwanych również w literaturze zagranicznej hotelami smart.

Reasumując zaprezentowane zagadnienia, można wysnuć wniosek, iż pojawienie się hoteli inteligentnych na rynku noclegowym jest niewątpliwie odpowiedzią na zapotrzebowanie społeczeństwa. Co prawda rola pracownika wydaje się kluczowa dla satysfakcjonujących doświadczeń gości hotelu (Grobelna i in. 2017; Grobelna 2016), jednakże współcześnie znaczenia nabiera nowoczesna technologia wdrażana w proces jego obsługi. Rozwiązania te nie tylko zwiększają wygodę gości, ale też pozwalają zwiększyć efektywność pracy w obiekcie, co może stanowić podstawę likwidacji współczesnego problemu, z którym boryka się obecnie branża, czyli brak kompetentnych pracowników i konieczność ciagłej optymalizacji procesów.

\section{HOTELE INTELIGENTNE W POLSCE - IDENTYFIKACJA OBIEKTÓW NA KRAJOWYM RYNKU NOCLEGOWYM}

Ponieważ polskie prawodawstwo dotyczące hotelarstwa nie przewiduje szczegółowego definiowania konkretnych rodzajów hoteli (np. butikowych, inteligentnych), bardzo trudno wskazać konkretną liczbę funkcjonujących w Polsce obiektów tego typu. Eksplorując zasoby internetowe, nie napotkano również na żaden, nawet ,subiektywny”, spis hoteli smart, co tylko świadczy o tym, iż tego rodzaju obiekt na polskim rynku hotelarskim stanowi jeszcze rzadkość.

Identyfikację hoteli inteligentnych na krajowym rynku noclegowym rozpoczęto od analizy prasy branżowej, na łamach której po raz pierwszy pojawiła się wzmianka o konkretnym (z nazwy) hotelu inteligentnym. Biorąc pod uwagę czasopisma branżowe z wieloletnim dorobkiem, wybrano za źródło miesięcznik „Hotelarz” wydawany w Polsce od 1962 r.

Analizując treść wszystkich artykułów i doniesień branżowych na łamach „Hotelarza” (od 2006 r.), za pierwszy hotel smart w Polsce w 2009 r. uznano hotel „Blow Up Hall 5050” w Poznaniu. Było to doniesienie branżowe poświęcone nadaniu kategorii pięciogwiazdkowej temu obiektowi („Hotelarz” 2010). Hotel ten określono jako luksusowy, innowacyjny technologicznie, designerski oraz podkreślono, iż jego pojawienie się na krajowym rynku hotelarskim zapoczątkowywało nowy trend na rynku. Poznański obiekt nie ma recepcji, a jednostki mieszalne nie mają numerów. Pojawiając się w hotelu, goście otrzymują iPhone'a, który umożliwia odnalezienie jednostki mieszkalnej i jej otwarcie. IPhone'y, dodatkowo wyposażone w informacje o obiekcie, centrum handlowo-kulturalnym „Stary Browar” i wydarzeniach kulturalnych Poznania, pełnią rolę wirtualnego concierge obiektu („Blow Up Hall 5050” 2018). Obiekt ten jest 
również specyficzny z powodu wszechobecnej sztuki, gdyż w jego wnętrzach znajdują się dzieła sztuki (w tym fotografie, instalacje świetlne), a każdy z pokoi jest niepowtarzalnie urządzony (Para 2013).

Innym źródłem identyfikacji hoteli inteligentnych na krajowym rynku noclegowym była korespondencja (metoda wywiadu korespondencyjnego) dotycząca zagadnienia hoteli inteligentnych skierowana do inspektora hotelowego, prowadzącego blog 3 o nazwie ENJOY YOUR STAY, poświęcony hotelarstwu. Autor bloga - K. Weber recenzuje i rekomenduje hotele, przedstawia ciekawostki z zakresu hotelarstwa oraz przeprowadza wywiady z hotelarzami (Weber 2017). Według autora bloga, zgodnie z treścią korespondencji elektronicznej, „w Polsce mianem hoteli inteligentnych określa się hotel »Sound Garden Hotel «w Warszawie, polskie hotele »Puro« czy »Smart Hotel Garnizon« w Gdańsku”.

W dalszej części artykułu zostanie przedstawiona charakterystyka ww. obiektów według daty ich powstania.

Przykładem hotelu inteligentnego, a w zasadzie sieci hoteli inteligentnych, jest marka „Puro”. Miastem, w którym zlokalizowano w 2011 r. pierwszy hotel tej sieci, był Wrocław (102 pokoje) („Hotelarz” 2010). Obecnie w ramach tej grupy hoteli funkcjonują jeszcze obiekty w Gdańsku (211 pokoi), Krakowie (135 i 228 pokoi) oraz Poznaniu (136 pokoi). W koncepcji rozwoju sieci obiektów „Puro” założono, że dzięki lokalizacji w centrum miasta, innowacyjnym rozwiązaniom technologicznym i nowoczesnemu wystrojowi wnętrz będą oferowane wysokiej jakości usługi (hotele są czterogwiazdkowe) w atrakcyjnej dla gości cenie. Rezerwacja pokoju jest możliwa za pośrednictwem internetowego systemu rezerwacji lub w samym hotelu przy użyciu panelu rezerwacyjnego. W hotelach nie ma tradycyjnej recepcji, gdyż maksymalne uproszczenie i skrócenie procedur czynią hotel niemalże samoobsługowym. Całą dobę do dyspozycji gości jest concierge (zwany również hostem), który interweniuje w razie potrzeby. Inteligentne rozwiązania dotyczą również pokoi hotelowych. Centralny panel dotykowy umożliwia sterowanie klimatyzacją oraz kolorem i natężeniem zainstalowanego oświetlenia ledowego. Bezpłatny dostęp do bezprzewodowego szerokopasmowego Internetu, darmowe rozmowy międzynarodowe, a także możliwość podłączenia sprzętu elektronicznego (laptopa, mp3 czy iPhone’a) do 40-calowego telewizora za pośrednictwem specjalnej konsoli umieszczonej przy łóżku tworzą w pokojach hotelowych idealne warunki zarówno do pracy, jak i wypoczynku (,Hotelarz” 2010). W modelu biznesowym sieci „Puro” przyjęto założenie, że większa automatyzacja rozwiązań generuje niższe koszty stałe

3 Blog - dziennik prowadzony przez internautę na stronach WWW - https://sjp.pwn.pl/ slowniki/bloger.html (data wejścia na stronę internetową: 9.11.2018). 
funkcjonowania obiektu, a w konsekwencji umożliwia kształtowanie niższej ceny usługi hotelowej. Takie podejście w prowadzeniu działalności hotelarskiej wydaje się skuteczne ekonomicznie, gdyż sieć „Puro”, jak wynika z informacji na internetowej stronie własnej marki, w 2019 r. ma otworzyć niebawem kolejne obiekty: w Łodzi oraz Warszawie („Hotel Puro” 2018).

Kolejnym obiektem smart jest trzygwiazdkowy hotel „Sound Garden” w Warszawie, który został otwarty w 2013 r., promując się hasłem „pierwszy inteligentny hotel w Warszawie” („Sound Garden” 2018) oraz „pierwszy samoobsługowy hotel w Warszawie” („Hotelarz” 2013). Hotel ma w swoim asortymencie 206 jednostek mieszkalnych i zgodnie z informacją na internetowej stronie własnej jest obiektem XXI w. Pod względem technicznym hotel gwarantuje szybkie łącze internetowe, lokalizację blisko lotniska oraz możliwość szybkiego self check-in'u, czyli samodzielnego zameldowania (należy wpisać jedynie numer rezerwacji, potwierdzić swoje dane osobowe i dane do faktury). Jeśli gość chce skorzystać z usług hotelu bez rezerwacji, może to zrobić przy pomocy elektronicznego kiosku, dzięki któremu można odebrać „klucz” do jednostki mieszkalnej. Zaraz po zameldowaniu faktura jest wysyłana na podany adres e-mail. Wymeldowanie odbywa się automatycznie, nie trzeba stać „w kolejce", można po prostu opuścić pokój. W razie potrzeby do całodobowej dyspozycji gości, zamiast recepcjonistów, są, tak jak w przypadku hotelu „Puro”, tzw. hostowie. W kwestii charakterystyki jednostek mieszkalnych są określane jako ergonomiczne i posiadają interaktywny stolik, dzięki któremu można połączyć się z TV za pomocą Plug \& Play ${ }^{4}$. Stolik posiada również panel sterujący oświetleniem oraz roletami, który pozwala, również podobnie jak w hotelach „Puro”, na zarządzanie całym oświetleniem pokoju bez przerywania pracy i zbędnego przemieszczania się („Sound Garden” 2018).

„Najmłodszym” przykładem hotelu inteligentnego na polskim rynku noclegowym jest dwugwiazdkowy „Smart Hotel Garnizon” w Gdańsku. Obiekt ten został otwarly w 2015 r. („Hotelarz” 2015) i w swojej ofercie ma 100 pokoi. Obiekt ten już z samej nazwy określany jest jako inteligentny, jednakże wnętrze także charakteryzują podobne rozwiązania technologiczne jak we wcześniej omówionych hotelach. Jednostki mieszkalne wyposażone są w 32-calowe, interaktywne telewizory full $\mathrm{HD}$, służące jako multimedialne centrum rozrywki. Zapewnią one gościom dostęp do Internetu, wirtualnej wypożyczalni filmów i gier, aplikacji Ipla i TVN Player, własnych urządzeń mobilnych czy funkcji smart

4 Plug and Play (z ang. podłącz i używaj) to termin używany na określenie zdolności komputera do pracy z urządzeniami peryferyjnymi zaraz po ich podłączeniu, bez konieczności ingerencji użytkownika w konfigurację sprzętową komputera. 
concierge, czyli wirtualnego przewodnika, którego funkcjonalność to pośrednictwo w zamówieniu wszelkich usług hotelowych i zewnętrznych („Hotelarz” 2015). Jedyną różnicą prezentowanego hotelu w porównania $\mathrm{z}$ tymi wcześniej zaprezentowanymi jest funkcjonowanie całodobowej recepcji. Oferta gdańskiego hotelu zawiera ponadto pewne atrakcyjne elementy dla klientów w kontekście określenia smart. Gość może wypożyczyć auto marki SMART (na godziny lub w systemie doby hotelowej) oraz skorzystać z hotelowej biblioteki, użyć czytnik kodów QR, wybrać najciekawszy tytuł, pobrać e-book i „zabrać książkę” do swojego pokoju („Hotel Smart” 2018).

Podsumowując niniejszą część opracowania (tab. 1), należy podkreślić, iż zidentyfikowano hotele smart, bazując w dużej mierze na subiektywnej ocenie. Taki stan rzeczy nakazuje ostrożność w interpretacji oraz wyciaganiu wniosków.

Tab. 1. Główne atrybuty zidentyfikowanych polskich hoteli inteligentnych (opracowanie: M. Sidorkiewicz)

Tab. 1. The main attributes of identified Polish smart hotels (author: M. Sidorkiewicz)

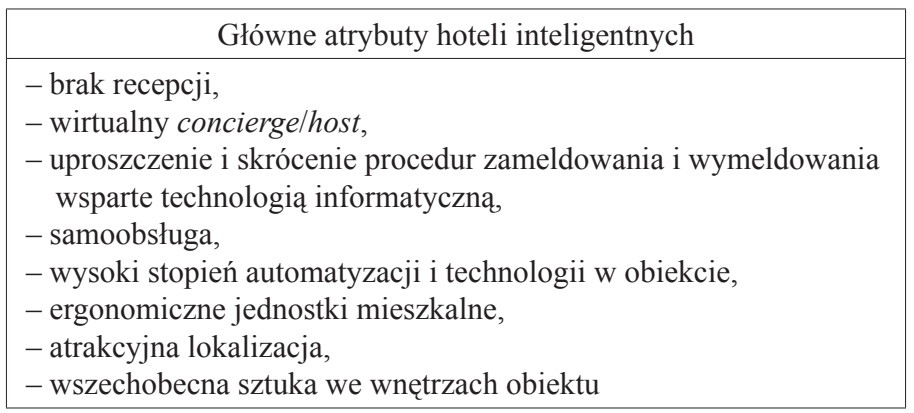

\section{HOTEL INTELIGENTNY - PRÓBA ZDEFINIOWANIA OBIEKTU}

Jak już wspomniano wcześniej, w polskim prawodawstwie nie ma przepisów, które jednoznacznie definiowałyby hotele inteligentne, ponadto polskie piśmiennictwo $\mathrm{w}$ tym zakresie jest dość skromne. W związku z tym próba teoretycznego ujęcia hotelu inteligentnego zostanie przeprowadzona w oparciu o charakterystykę zaprezentowanych przykładów hoteli, doniesienia branżowe oraz uregulowania prawne, które dotyczą hoteli ogółem.

Zgodnie z polskim prawem, a dokładnie z ustawą o usługach hotelarskich oraz usługach pilotów wycieczek i przewodników turystycznych, żeby obiekt funkcjonujący na rynku zakwaterowania zbiorowego mógł być określony prawnie chronioną nazwą „hotel”, musi spełniać pewne warunki. Hotel musi 
dysponować liczbą co najmniej 10 pokoi o określonej strukturze, mianowicie w większości jedno- i dwuosobowych. Ponadto powinien oferować szeroki zakres usług związanych z pobytem gości (Ustawa 1997).

Chociaż hotel smart w teorii nie został jeszcze do końca opisany, jednak w praktyce jest on dobrze znany i jednoznacznie kojarzony. Według K. Webera mianem hotelu inteligentnego określa się zwykle „hotele samoobsługowe”. $\mathrm{W}$ hotelach tego rodzaju zamiast tradycyjnej hotelowej recepcji występują systemy komputerowe, umożliwiające gościom samodzielne zameldowanie się, a następnie wspomagające gościa podczas samego pobytu w hotelu i wreszcie realizujące procedurę check out, z obowiązkową płatnością przy pomocy kart płatniczych. Stopień zautomatyzowania w przypadku tych hoteli jest niezwykle duży, gdyż większość świadczonych w nich usług realizowana jest bez udziału pracowników, z wykorzystaniem nowoczesnych systemów i aplikacji (Puciato 2016; This High-Tech Hotel Room Will Blow Your Mind 2018).

W obiektach występują również inteligentne instalacje umożliwiające zarządzanie: energią elektryczną, cieplną czy wentylacją (Puciato 2016). Dzięki możliwości sterowania wszystkimi pokojami można wyłączyć ogrzewanie w tych, które są w danym momencie nieużywane. Ogrzewanie włączy się ponownie automatycznie w momencie zameldowania się w nim klienta (Kłosowska 2017). Ponadto w takich hotelach instalacje zamykają lub otwierają zasłony, zapewniają ochronę przed zbyt intensywnym nasłonecznieniem i utrzymują optymalną temperaturę we wnętrzach. Obliczono, że obniżenie temperatury o $1{ }^{\circ} \mathrm{C}$ pozwala na redukcję kosztów ogrzewania aż o 4\% („Hotelarz” 2012), zatem są to już wymierne korzyści finansowe.

Z punktu widzenia branży hotelarskiej na rynku są już dostępne rozwiązania do inteligentnego zarządzania hotelem, czego przykładem jest system wyceny usług. Dzięki temu produktowi można precyzyjnie określić, ile powinna wynosić cena wynajmu jednostki mieszkalnej w obiekcie, aby pokryć koszty zmienne, stałe i zaprogramować zysk w budżecie. Pozwala on na porównanie i śledzenie kosztów pokoju sprzedanego w stosunku do dostępnego, poznanie minimalnego poziomu obłożenia, który pokryje wszystkie koszty przy danej cenie, pomaga oszacować koszty stałe hotelu i marżę usługi hotelowej. Poza korzyściami typowo finansowymi są też korzyści kadrowe. To rozwiązanie ułatwia znalezienie osoby odpowiedzialnej zarówno za „sukces”, jak i „porażkę” w hotelu, a więc kontrolowanie efektywności pracowników. Dostarcza bowiem wiedzy o wynikach finansowych wszystkich składowych, czyli tzw. centrów biznesowych / centrów zysku w obiekcie (Kłosowska 2017).

Tego rodzaju oprogramowanie zapewnia też najwyższy poziom zabezpieczenia budynku, który pozwala na kontrolę dostępu do poszczególnych stref 
czy pokojów, dzięki czemu minimalizuje ryzyko dostania się do strzeżonych pomieszczeń przez osoby nieuprawnione („Hotelarz” 2012).

Omawiany system jest elastyczny w konfiguracji i skalowalny, co oznacza, że poszczególne elementy rozwiązania mogą być wykorzystywane razem lub pracować osobno oraz że mogą być wykorzystywane w obiektach hotelowych o różnej skali działania („Hotelarz” 2008).

Można więc przyjąć, iż hotele inteligentne cechują innowacje technologiczne. Do przykładów innowacyjnych rozwiązań technologicznych wykorzystywanych w branży hotelarskiej poza Polską, oprócz wskazanych wcześniej, można zaliczyć także (Weber 2015):

- wyposażenie pokoju w czujnik ruchu i czujnik drzwi, dający możliwość naliczania opłat na rachunek gościa (np. za minibar), zmianę statusu pokoju (z zajętego na wolny, z brudnego na czysty),

- wykorzystywanie robotów do odbioru od gościa bagażu i chowania go do szafki w przechowalni,

- używanie czytnika twarzy zamiast klucza do drzwi,

- automatyczne dostosowanie temperatury powietrza w pokoju do temperatury ciała gościa,

- humanoidalną obsługę recepcyjną (roboty umieją porozumieć się z gośćmi w czterech językach) (6 trends shaping smart hotels 2018).

Omawiając rozwiązania technologiczne stosowane w hotelach inteligentnych, należy podkreślić fakt, iż pojawienie się na rynku hotelarskim tego typu obiektów wpisuje się w zagadnienie tzw. Internetu rzeczy (ang. internet of things) (Carlino 2016; Greengard 2015), którego podstawowym celem jest stworzenie inteligentnych przestrzeni (np. inteligentnych budynków). Internet rzeczy uważany jest za swoisty ekosystem, w którym wyposażone w sensory przedmioty komunikują się z komputerami (Rudnicki i in. 2017).

Podsumowując specyfikę hoteli smart w odniesieniu do technologii, należy wyraźnie zaznaczać - po stronie usługodawcy - wykorzystanie informacyjnych i komunikacyjnych technologii w celu zwiększenia efektywności i wyższej jakości świadczonych usług, natomiast po stronie klienta - otrzymanie wygody i satysfakcji.

Biorąc pod uwagę doniesienia branżowe oraz strony internetowe poszczególnych obiektów, które określane są mianem inteligentnych, by obiekt był odbierany jako smart, wdrożenie tylko samych innowacji technologicznych nie jest wystarczające. Kluczowa dla hoteli inteligentnych wydaje się bowiem również lokalizacja obiektu na obszarze miasta, która z reguły stanowi jego centrum życia kulturalnego i społecznego, jest w sąsiedztwie obiektów restauracyjnych, kin, teatrów czy zabytków lub blisko portów komunikacyjnych (np. lotnisk, dworców). 
Nie bez znaczenia dla hoteli inteligentnych jest także związek z szeroko rozumianą kulturą i sztuką. Efektem tego aspektu może być design obiektu, mający niewątpliwie swój charakter. Jest on wyrażony przez architekturę i wystrój wnętrz utrzymany w nowoczesnym, minimalistycznym i często oryginalnym stylu. Powierzchnia jednostek mieszkalnych w niektórych hotelach jest nieduża, co może nie odpowiadać każdemu gościowi, jednakże uzasadnieniem dla niedużych rozmiarów pokoi jest fakt, iż mają one służyć jedynie w celach noclegowych, a nie w celu całodziennego spędzania w nich czasu. Pokoje mają być funkcjonalne, $\mathrm{z}$ dużą liczbą łatwo dostępnych gniazdek elektrycznych do naładowania telefonu, tabletu i laptopa (Weber 2016). Design dotyczy także części ogólnodostępnych, które zwykle są powiększone i urozmaicone pod względem liczby rozrywek i urządzeń, tworząc strefę spotkań i relaksu (tzw. chill zone).

Szukając różnic pomiędzy prezentowanymi hotelami, można zauważyć również fakt, iż tego rodzaju obiekty mogą mieć różny standard. Tak więc kategoryzacja nie wpływa na specyfikę hoteli smart, która odróżnia te obiekty od innych, co ma miejsce w przypadku np. hoteli butikowych.

Reasumując rozważania wynikające $\mathrm{z}$ charakterystyki zaprezentowanych hoteli oraz doniesień branżowych, można podjać próbę zdefiniowania hotelu inteligentnego, który należy określić jako obiekt hotelarski:

- wysoko zautomatyzowany, z reguly pozbawiony tradycyjnej recepcji,

- wykorzystujący nowoczesne technologie wymagające używania przez klientów urządzeń mobilnych w celu konsumowania usług hotelarskich,

- wyróżniający się wykorzystaniem w jego wystroju elementów szeroko rozumianej sztuki, kultury i designu,

- zlokalizowany $\mathrm{z}$ reguły $\mathrm{w}$ centrum miasta lub $\mathrm{w}$ pobliżu dróg komunikacyjnych.

\section{WNIOSKI}

Potrzeby noclegowe współczesnych gości hotelowych, przede wszystkim z pokolenia $\mathrm{Y}$, determinują kreowanie nowych rodzajów obiektów hotelarskich. Urządzanie mobilne i towarzyszące im aplikacje są już nieodłącznymi towarzyszami podróży hotelowych konsumentów, bez różnicy, czy przyjeżdżają oni w celach biznesowych, czy osobistych. Obecnie klient oczekuje od obiektu czegoś więcej niż tylko wygodnego łóżka i bezpłatnego dostępu do sieci internetowej, dlatego zarządzający obiektami lub nowi inwestorzy powinni przemyśleć wdrożenie inteligentnych rozwiązań w swoich obiektach. Wykorzystanie bowiem technologii w hotelu, ze względu na aktualne potrzeby gości, może zwiększyć jego 
konkurencyjność oraz pozwolić zoptymalizować czas i koszt niektórych procesów. Dlatego też koncepcja inteligentnych budynków, która jeszcze do niedawna była zarezerwowana wyłącznie dla wielkomiejskich biurowców, coraz częściej dedykowana jest hotelowym gościom w postaci hotelu inteligentnego, zwanego również hotelem smart.

O ile jeszcze dzisiaj wszechobecne udogodnienia technologiczne nie są standardem, to już niedługo, kiedy pokolenie Y zdominuje stronę popytową rynku zakwaterowania zbiorowego, obiekty, które nie wezmą pod uwagę potrzeb tej rosnącej grupy, mogą zostać postrzegane jako mniej atrakcyjne, a tym samym będą rzadziej wybierane przez młode pokolenie jako miejsce zakwaterowania. Należy jednak podkreślić, iż hotele inteligentne wpisują się nie tylko w potrzeby noclegowe pokolenia $\mathrm{Y}$, ale także X, które jest licznie reprezentowane przez kadrę menedżerów korzystających na co dzień z technologii informacyjno-komunikacyjnych.

Taki stan rzeczy pozwala przypuszczać, że tego rodzaju obiektów hotelarskich będzie w kontekście ilościowym na rynku przybywać. Można też podejrzewać, iż będą się one zmieniać pod względem jakościowym, choćby ze względu na fakt szybkiego rozwoju różnorodnych technologii wyróżniających ten rodzaj obiektu spośród innych.

Nie można jednak zapominać, iż istotą hotelarstwa jest gościnność oparta na emocjach, nawiązywaniu i podtrzymywaniu relacji, co jest efektem zatrudniania kompetentnej kadry. W hotelu inteligentnym obsługa powinna być sprawna i dobrze zorganizowana, a wyposażenie jednostki mieszkalnej funkcjonalne i zapewniające maksymalny komfort. I temu właśnie powinny służyć nowoczesne technologie w tego typu obiektach, czyli być elementem wsparcia procesu obsługi, nie zaś zastępować człowieka.

\section{LITERATURA}

Aruna M., Anitha J., 2015: Employee retention enablers: Generation Y employees. SCMS Journal of Indian Management, 12 (3), 94.

Bolton R.N., Parasuraman A., Hoefnagels A., Migchels N., Kabadayi S., Gruber T., Loureiro Y.K., Solnet D., 2013: Understanding Generation $Y$ and their use of social media: a review and research agenda. Journal of service management, 24 (3), 245-267. https://doi. org/10.1108/09564231311326987

Brown E.A., Thomas N.J., Bosselman R.H., 2015: Are they leaving or staying: A qualitative analysis of turnover issues for Generation Y hospitality employees with a hospitality education. International Journal of Hospitality Management, 46, 130-137. https://doi.org/10.1016/j. ijhm.2015.01.011

Carlino N., 2016: Internet of Things is a good entry point for smart hotels. Hotel Business, nr 7.03, 48. 
Gołąb-Andrzejak E., 2016: Konsumenci pokolenia Y-nowe wyzwanie dla komunikacji marketingowej. Handel Wewnętrzny, nr 2, 140-143.

Greengard S., 2015: The internet of things, MIT Press.

Grobelna A., 2016: Challenge stressors in the hospitality industry and their impact on employees' performance, [w:] F. Pinzaru, C. Bratianu (eds.), Proceedings of the $12^{\text {th }}$ European Conference on Management, Leadership And Governance ECMLG 2016. Academic Conferences and Publishing International Limited, UK, 71-79.

Grobelna A., Dębski M., Górska-Warsewicz H., 2017: Marka jako źródło ksztaltowania konkurencyjności w branży turystycznej. Difin, Warszawa.

Kachniewska M., Para A., 2014: Pokolenie Y na turystycznym rynku pracy: fakty, mity i wyzwania. Rozprawy Naukowe Akademii Wychowania Fizycznego we Wrocławiu, nr 45, 155.

Kot P., 2016: Preferencje typu kultury organizacyjnej u przedstawicieli różnych generacji. Marketing i Rynek, nr 2, 33.

Kultalahti S., Viitala R., 2015: Generation Y-challenging clients for HRM?. Journal of Managerial Psychology, 30 (1), 101-114. https://doi.org/10.1108/JMP-08-2014-0230

Para A., 2013: Przejawy i uwarunkowania innowacyjności obiektów hotelowych, [w:] P. Dominik (red.), Innowacyjne rozwiąania we współczesnym hotelarstwie. Almamer Szkoła Wyższa, Warszawa, 63.

Pawlicz A., 2012: E-turystyka. Ekonomiczne problemy implementacji technologii cyfrowych w sektorze turystycznym. Wydawnictwo Naukowe PWN, Warszawa.

Puciato D., 2016: Przedsiębiorstwo hotelowe. Aspekty ekonomiczne, finansowe i organizacyjne. Difin, Warszawa.

Rudnicki M., Borodako K., 2017: Internet rzeczy w infrastrukturze portu lotniczego jako element usprawnienia obstugi ruchu turystycznego, [w:] Prace Naukowe Uniwersytetu Ekonomicznego we Wrocławiu nr 473 (Gospodarka turystyczna w regionie. Przedsiębiorstwo. Samorzad. Wspótpraca). Uniwersytet Ekonomiczny we Wrocławiu, Wrocław, 489-506.

Ustawa z dnia 29 sierpnia 1997 r. o usługach hotelarskich oraz usługach pilotów wycieczek i przewodników turystycznych, Dz.U. 1997, nr 133, poz. 884.

\section{NETOGRAFIA}

Hotel Marketing \& Technology. Trends 2017, https://www.profitroom.pl/trends (dostęp: 18.08.2017). http://www.e-hotelarz.pl/mht/artykul/16443/inteligentny-hotel-galaxy.html (dostęp: 9.11.2018).

http://www.e-hotelarz.pl/mht/artykul/17006/hotel-inteligentny-czyli-oszczedny.html (dostęp: 09.11.2018).

http://www.e-hotelarz.pl/mht/artykul/20305/sound-garden-\%E2\%80\%93-samoobslugowy-hotelw-warszawie.html (dostęp: 9.11.2018).

http://www.e-hotelarz.pl/mht/artykul/27947/hotele-przyszlosci-dzialaja-juz-dzis.html (dostęp: 9.11. 2018).

http://www.e-hotelarz.pl/mht/artykul/8339/inteligentny-hotel-lsi-software-zdobywa-zloty-medalmiedzynarodowych-targow-poznanskich.html (dostęp: 9.11.2018).

http://www.e-hotelarz.pl/mht/artykul/8638/piec-gwiazdek-dla-hotelu-blow-up.html (dostęp: 9.11. 2018). 
http://www.soundgardenhotel.pl/inteligentny-hotel-w-warszawie (dostęp: 16.08.2017).

http://www.soundgardenhotel.pl/nowoczesne-pokoje-w-warszawie (dostęp: 16.08.2017).

Kłosowska A., Inteligentny hotel na kilka sposobów, http://www.rp.pl/artykul/939120-Inteligentny-hotel-na-kilka-sposobow.html\#ap-1 (dostęp: 9.11.2018).

Stańczak K., Jak sprzedawać tym, którzy nie maja potrzeby posiadania?, https://www.forbes.pl/ opinie/millenialsi-pokolenie-y/lfbx6sg (dostęp: 9.11.2018).

http://mentalfloss.com/article/64904/10-innovative-hotel-room-features-will-blow-your-mind (dostęp: 3.01.2019).

https://www.bdcnetwork.com/6-trends-shaping-smart-hotels (dostęp: 3.01.2019).

http://www.hotelsmart.pl/pl/smarthotel/obsluga/ (dostęp: 17.08.2017).

https://sjp.pwn.pl/slowniki/bloger.html (dostęp: 17.08.2017).

http://www.blowuphall5050.com/hotel/ (dostęp: 20.07.2018).

http://purohotel.pl/pl (dostęp: 09.11.2018).

http://www.e-hotelarz.pl/mht/?p=29608 (dostęp: 9.11.2018).

http://www.e-hotelarz.pl/mht/?p=29608 (dostęp: 9.11.2018).

http://www.e-hotelarz.pl/mht/?p=8709 (dostęp: 9.11.2018).

http://www.e-hotelarz.pl/mht/?p=8709 (dostęp: 9.11.2018).

http://www.enjoyyourstay.pl/hotele-high-tech/ (dostęp: 9.11.2018).

http://www.enjoyyourstay.pl/hotele-nowego-pokolenia/ (dostęp: 9.11.2018).

http://www.enjoyyourstay.pl/o-autorze/ (dostęp: 9.11.2018). 